\title{
The Determinants of Using Bank Loans by Women Entrepreneurs: Comparative Study Between Middle East and Western Europe Countries
}

\author{
Hani EL-Chaarani ${ }^{1} \&$ Zouhour EL-Abiad $^{2}$ \\ ${ }^{1}$ Faculty of Business Administration, Beirut Arab University, Lebanon \\ ${ }^{2}$ Faculty of Economic Sciences and Business, Lebanese University, Lebanon \\ Correspondence: Hani EL-Chaarani, Faculty of Business Administration, Beirut Arab University, Tripoli, \\ Lebanon. Tel: 96-1311-7789. E-mail: h.shaarani@bau.edu.lb
}

Received: October 9, $2019 \quad$ Accepted: October 23, $2019 \quad$ Online Published: November 19, 2019
doi:10.5539/ass.v15n12p114
URL: https://doi.org/10.5539/ass.v15n12p114

\begin{abstract}
The intention of this research is to provide more evidence related to women entrepreneurs by selecting an unexplored sample coming from two different regions: The Middle East and the Western Europe countries. It aims to explore the profile of women entrepreneurs and to further investigate the impact of their socio-demographic profile and their individual subjective perception on their preference for bank loans.

The sample was composed of 47 and 46 women entrepreneurs operating in small and medium (SMEs) business activities, respectively in 10 Middle East and 10 Western Europe countries. Results show that the majority of women entrepreneurs in both regions are between 26 and 31 years old, they have a high education level, they have already received a training support and accumulate an important professional experience. The majority of women entrepreneurs also avoid using bank loans. However, women entrepreneurs in the Middle East have more conflict between their entrepreneurial activity and their family duties. Regressions results show that socio-demographic variables of women entrepreneurs, such as the age, the education level, the training support and the professional experience affect positively and significantly the use of bank loans in both regions. Other variables related to family issues such as the marital status, the family size and the family responsibilities provide a negative and significant impact. The subjective perception variables of women entrepreneurs such as the risk tolerance, the self-confidence and the confidence in banks affect negatively on the use of bank loans.
\end{abstract}

Keywords: women entrepreneurs, bank loans, socio-demographic profile, subjective self-perception

\section{Introduction}

Women and entrepreneurship are actually considered as fast-growing areas of research in management (Vogel, 2017; Collins \& Low, 2010; Schindehutte et al., 2008; Bird \& Brush, 2002). Theoretically, the literature in this domain has been gaining a large popularity in recent decades (Hughes et al., 2012). Researches are divided in two principal groups, the personalities and traits of women entrepreneurs and the factors that affect women entrepreneurship. Empirically, it is widely recognized that women entrepreneurs represent an ever-increasing proportion in the world, and that they make a dynamic contribution to the international entrepreneurial process (Welsh et al., 2016). Recent researchers have considered more attention on analyzing the influence of women behavior on the financial decision making. Literature recognize that in general women entrepreneurs tend to have less access to external funding sources, especially bank loans (Huang \& Kisgen, 2013). Different justifications can be given in this regard.

As for the business character, women entrepreneurs who have less growth aspirations, tend to go through small and medium projects (Heidrick \& Nicol, 2002; Orhan, 2001). Thus, they request for less needs of loans.

The socio-demographic characteristics of women are also considered by some studies as individuals factors influencing the decision making of female entrepreneur. The most common studied factors are the age (Brauw \& Eozenou, 2014), the marital status (Weber, 2013), the family issues (Noor et al., 2014), the level of education (Brauw \& Eozenou, 2014), the professional training (Fairlie \& Holleran, 2012), the managerial competence (St-Cyr, 2002) and the professional experience (Roomi et al., 2009). 
By referring to the personal character, women entrepreneurs have some individual subjective perception factors that determine their financial tendencies. Generally, they rely more on internal financial support and funds from family and friends (Alam et al., 2011). The fear of failure, the fear of risk (Castillo \& Feer, 2018), the lack of confidence in themselves (Barua et al., 2010; Peni \& Vahamaa, 2010) and the lack of confidence in financial institutions lead them to avoid banks loans (Fabowale et al., 1995; Buttner \& Rosen, 1992).

By considering the credit suppliers side, many studies found that women entrepreneurs face more credit constraints than their male counterparts. Banks are accused to have a gender discrimination in loans granting (Kwong et al., 2012; Belluchi et al., 2010; Muravyev et al., 2007) (Note 1).

Accordingly, the subject related to the use of bank loans by women entrepreneurs needs more clarification by relying on a worldwide investigation. A gap in literature needs to be filled by analyzing why women entrepreneurs have less use of bank loans.

For this reason, this research has two main objectives. First, it provides more attention to the profile of women entrepreneurs in two different regions, the Middle East and the Western Europe countries. And thus, it contributes to understand the actual individual characteristics of women entrepreneurs. Second, this study explains how woman entrepreneur's individual factors could affect, positively or negatively, her preference for bank loans. So, it clarifies how the socio-demographic profile and the individual subjective perception of women entrepreneurs affect their depending on commercial credits.

Despite the lack of information and given the complications of identifying the sample of women entrepreneurs, the data collection was constructed through different steps. The empirical study based on a structured online questionnaire and a sample of 47 and 46 women entrepreneurs operating respectively in Small and Medium (SME) business related to service activities, in 10 Middle East and 10 Western Europe countries attempts its objective.

Thus, the results provide significant professional and literature contributions. They present significant knowledge on women entrepreneurs and clarify important aspects associated to the relation between their individual characteristics and their use for bank loans.

The research is divided into three principal parts: section (2) presents the individual factors of women entrepreneurs, section (3) describes the setting of the methodology issues, section (4) presents the results, and finally section (5) concludes the article.

\section{Individual Factors of Women Entrepreneurs}

Research shows that, beyond business features, the socio-demographic characteristics of women entrepreneurs (2.1), as well as their individual subjective perceptions (2.2), can strongly influence their financing patterns.

\subsection{Socio-Demographic Profile of Women Entrepreneurs}

Literature suggests that the socio-demographic profile of women such as age, marital status, family size, family responsibilities, education level, training support and professional experience are considered as important factors that affect their financial behavior.

\subsubsection{Age of Women Entrepreneurs}

The age of women entrepreneurs shows confusing conclusions. Some studies suggest that with the increase in age, the accumulated experiences enable the entrepreneur to deal with riskier situations and to manage the business challenges (Brauw \& Eozenou, 2014; Levesque \& Minniti, 2006). According to this result, women entrepreneurs build a valuable experience with age increasing and they will be more able to support the financial risk derived from bank loans. Robb and Wolken (2002) found that female entrepreneurs are younger than male entrepreneurs and have a comparatively poor credit history. So, the age of women entrepreneur and the bank loans are positively related. However, few other studies have found that young entrepreneurs are more motivated and ambitious. They tend to bear risker issues to maximize the profit of the business (Adhikary et al., 2011). Therefore, when ambitious young women entrepreneurs are guided by the profit maximization objective, they will be more motivated to accept the financial risk of bank loans. Thus, the age of women entrepreneurs and the bank credits are related negatively.

\subsubsection{Marital Status and Family Issues of Women Entrepreneurs}

The marital status and the family aspects are considered as important determinants on women entrepreneur's willingness to go into debt financing. Studies show that married women entrepreneurs have to cope with the double familial and professional responsibilities, by balancing work and family demands (Noor et al., 2014, Johan et al., 2013). Accordingly, the financing decision of women entrepreneurs are influenced by the family 
size and the family responsibilities. Indeed, having bigger families with more adult members allows them to support more risk (Gong \& Yang, 2012) and lead them to tolerate bigger amounts of credits. But, having more family responsibilities along with childcare increase their risk aversion (Constantinidis et al., 2006; Weber, 2013), and lead them to request smaller amounts of credits (Danmanville \& Hurel, 2001; St-Cyr, 2002).

\subsubsection{Education Level and Training Support of Women Entrepreneurs}

Education and training support show an important role in the context of female entrepreneur. Studies in entrepreneurship confirm the negative association of education and training with business risk- averse. Results consider that an entrepreneur with higher level of education may obtain and understand information about business opportunities and risks. With education and training, women entrepreneur improves her individual's ability to resolve the problem of asymmetric information about the business future outcomes. Therefore, entrepreneur with higher educational level is less likely to be risk- averse (Knight et al., 2003; Fairlie \& Holleran, 2012). Fairlie and Holleran (2012) consider that the initial level of training and supports motivate entrepreneurs to bear more risk and start a new business. Knight et al. (2003) find that the educational level of women entrepreneur tends to decrease her risk aversion and to recognize more business opportunities through indirect effect on the access to credit. When Coleman (2004) includes educational level as an independent variable in his empirical study, he finds that most women entrepreneurs have a low level of education and this could be a specific barrier to the use of bank loans.

\subsubsection{Entrepreneurial Experience of Women Entrepreneurs}

The entrepreneurial experience of women entrepreneurs was also studied in literature as determinants of business opportunities, business risk taking, business performance and business financing choices. Several authors consider that women entrepreneurs may have lower entrepreneurial and managerial experience than men entrepreneurs (Boden \& Nucci, 2000; Danmanville \& Hurel, 2001; Greene et al., 2001; Orhan, 2001; St-Cyr, 2002). By regarding to the financing choices, the lack of financial competence makes women entrepreneurs feel insecure in financial negotiations (Dahalan et al., 2013) and lead bankers to reject their loans applications (Haines et al., 1999). However, the experience of entrepreneur is found to have a significant positive relation with business performance (Jose et al., 2014). Thus, the low experience of women entrepreneurs in handling business management causes barriers for the improvement and the performance of their business (Roomi et al., 2009). Bankers consider that they have an insufficient personal experience for starting a new business (Heidrick \& Nicol, 2002; St-Cyr, 2002). As a result, women entrepreneurs will have significant barrier to access to bank loans (Danmanville \& Hurel, 2001).

\subsection{Individual Subjective Perception}

\subsubsection{Risk-Aversion of Women Entrepreneurs}

It's widely believed that attitude towards risk affects entrepreneurship in terms of investment, production, marketing and financial resources choices (Bortamuly et al., 2014; Hazarika \& Goswami, 2014). It implies that the success of the entrepreneurial activity depends on how entrepreneur undertakes and manages the associated business and financial risks involvement (Blunch et al., 2001). From a gender perspective, empirical studies demonstrate that risk-attitude differs between women and men in entrepreneurship. The vast majority of the results in literature illustrate that female entrepreneurs are more risk-averse than their counterparts (Kepler \& Shane, 2007; Neelakantan, 2010; Yordanova \& Alexandrova-Boshnakova, 2011). To our knowledge, only one study shows that risk -taking propensity of women can exceed that of men. This single opposite result was recently stated by Castillo et al. (2017). Authors provide evidence that female entrepreneurs are more risk taking than their male counterparts, because they are forced to brake the barriers of their success by supporting higher risk levels. These evidences were observed in two vibrant markets in Lima and Peru, which have been characterized by a competitive environment of self-employment.

With regards to financial decisions, the gender matter is extremely important. It is argued in literature that women are more risk averse in their willingness to take financial risks (Croson \& Gneezy, 2009; Dwyer et al., 2002). Due to their risk-aversion, female entrepreneurs are less likely to approach banks for loans granting as compared to their male entrepreneurs' counterparts (Bardasi et al., 2011). They tend to have lower debt levels, which maybe because female entrepreneurs try to reduce the costs of bankruptcy and are reluctant to provide the guarantees requested for loans acceptance (Carter \& Cannon, 1992). Similar results were also observed for female CFOs and CEOs who are more likely to decrease the leverage levels of their firms compared with their male counterparts (Huang \& Kisgen, 2013, Faccio et al., 2015). 


\subsubsection{Self-Confidence of Women Entrepreneurs}

The confidence level is considered as an important subject in decision-making studies. It depends on the uncertainty and the complexity of the task. The overconfidence may arise when women entrepreneur is about to underestimate her level of risks and to overestimate her knowledge (Powell \& Ansic, 1997). Literature suggests that gender differences affect the overconfidence level. Dittrich et al. (2001) provide evidence that the overconfidence of women decreases when uncertainty is high and it decreases with the complexity of task. However, in case of financial decision, a less overconfidence is displayed by women entrepreneurs than do men entrepreneurs (Bengtsson et al., 2004). The reason behind this result is that women mostly try to avoid being involved in financial issue. And when they are obliged to go through it, they become more nerves and select the decision that offers the lower degree of risk (Stinerock et al., 1991). Generally, women lose their self- confidence when they make a financial decision. They feel afraid of being wrong and prefer to seek for more advice from others (Peni \& Vahamaa, 2010; Barua et al., 2010).

Some authors suggest that the lack of confidence create a problem for female entrepreneurs while they intend to have external financial resources. They appear less convincing while presenting their business ideas to banks (Becker-Blease \& Sohl, 2011). For this reason, women entrepreneurs are considered not to have enough selfconfidence to acquire external financing in the early stages of their business (Becker-Blease \& Sohl, 2011; Carter et al., 2007). So, they face difficulties in obtaining debt financing through bank loans, as well as equity financing through venture capital and business angels (OECD, 2000; Danmanville \& Hurel, 2001; St-Cyr, 2002). Thus, it is not surprising to find on the Canadian market, that the rejection rate of bank loan applications amounted for $23 \%$ for women entrepreneurs, compared with only $10 \%$ for men entrepreneurs in 1997 (St-Cyr et al., 2003). And also, to find on the French market that women entrepreneurs were asked for higher collateral requirements and charged a higher interest rate than their men counterparts (Orhan, 2001).

\subsubsection{Less Confidence Level of Women Entrepreneurs Towards Banks}

Women entrepreneurs tend to use internal financial resources. They seem to be not comfortable with external ones in general, and with bank loans in particular (Chaganti et al., 1995). Constantinidis et al. (2006) assume that women entrepreneurs have negative representations and feelings towards bank financing. Buttner and Rosen (1992) and Fabowale et al. (1995) found that women entrepreneurs are more likely to report feelings of being treated disrespectfully by banks. Regarding the last statements, it can be concluded that women entrepreneurs avoid even applying for bank loans.

Previous studies have reported a similar trend for female entrepreneurs, who mainly use their personal savings and credit cards instead of applying for bank financing. In case of financial needs, they prefer to have the resources from family and friends, rather than using banks loans or commercial credit (Orhan, 2001; Robb \& Wolken, 2002; St-Cyr, 2002). Furthermore, family and friends are considered as the trusted sources of help for women entrepreneurs, especially in the start-up stage of their business (Brindley, 2005).

Women entrepreneurs are less likely than men to take out a loan, even if it was a line of credit. As already stated, they are more likely to cover their financial needs by using credit cards than men (Coleman, 2004). Robb and Wolken (2002) also found lower loan application rates for female entrepreneurs compared to their men counterparts. They concluded that women entrepreneurs were less likely to have applied for a bank loan than men within the previous three years of their study.

\section{Settings of the Methodology Issues}

\subsection{Field Study Definition}

By considering past academic researches, several empirical studies had focused on exploring the portray of women's entrepreneurial traits, behaviors and factors that affect their managerial decisions, in one single country. However, some studies had compared between two selected countries and others had been interested in a cross-country sample (Table 1 ).

Table 1. Women entrepreneur in cross countries researches

\begin{tabular}{ll}
\hline One country & \\
\hline China & Au et al. (2013), Au and Kwan (2009) \\
Poland & Walczak and Pienkowska-Kamieniecka (2018), Klonowski (2010) \\
Spain & Pérez-Pérez and Avilés-Hernández (2016) \\
India & Ansari (2016) \\
France & Orhan (2001) \\
\hline
\end{tabular}




\begin{tabular}{ll}
\hline Lebanon & Trad (2015), Khalife and Chalouhi (2013) \\
Pakistan & Hussain et al. (2014) \\
Saudi Arabia & Diane et al. (2014), Danish and Smith (2012) \\
\hline Two countries & \\
\hline Austria and Hungary & Filser et al. (2014) \\
Russia and Ukraine & Iakovleva et al. (2013) \\
Czech Republic and Poland & Lituchy and Reavley (2004) \\
\hline Cross-country sample & \\
\hline Latin America and Spain & Villasana et al. (2016) \\
17 European countries & Ongena and Popov (2013) \\
Western countries & Collins and Low (2010) \\
44 developed and developing countries & Kobeissi (2010) \\
15 EU member countries and the USA & Grilo and Irigoyen (2005) \\
\hline
\end{tabular}

This study is in line with the cross-country sample researches because it explores both of Middle East and Western Europe regions. It is unique since it is the first research that provides a diversified sample coming from two different regions with different culture and economic environment. Ten different countries are selected from Middle East region (Cyprus, Lebanon, Jordan, Saudi Arabia, Kuwait, Qatar, Bahrain, United Arab Emirates, Oman and Yemen). Also, ten other countries are designated from Western Europe (Note 2) (Portugal, France, Spain, Belgium, Germany, Greece, the United Kingdom, Ireland, Italy and Luxembourg).

\subsection{Model, Questionnaire and Variables}

The main objective of the study is to investigate if the women entrepreneurs' individual factors may influence their preference for bank credits. The paper focus on testing how subjective perception and social demographic characteristics of women entrepreneurs could affect their desire to apply for bank loans. The socio-demographic profile of women entrepreneurs and their subjective perception are the independent variables, while use of bank loans is the dependent variable (Figure 1).

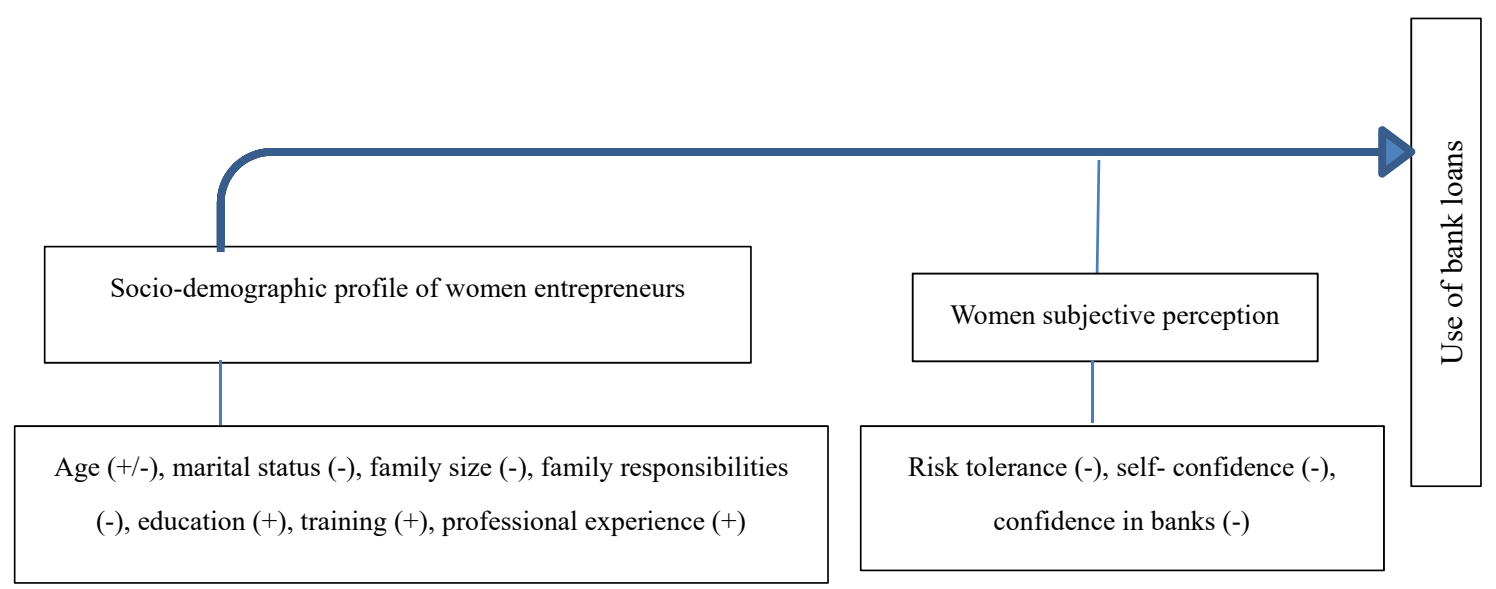

Figure 1. Research model

The data is collected through a structured online questionnaire divided in two principal parts. The first one is composed of 8 close ended questions related to the socio-demographic profile of women entrepreneurs. The second one is composed of 3 close ended questions related to women subjective perception. The last question is about the use of bank loans by women entrepreneurs. In total, the questionnaire consists of 12 close ended questions prepared using 5-point Likert Scale (Likert, 1972) and binary scale (Table 2).

Table 2. Variables definition

\begin{tabular}{cc}
\hline \multicolumn{2}{c}{ Independent variables } \\
\hline 1. Social and demographic characteristics of women entrepreneurs & 2. Subjective perception of women entrepreneurs \\
\hline Age $[\mathrm{AG}]$ & Risk tolerance $[\mathrm{RT}]$ \\
Marital status $[\mathrm{MS}]$ & \\
\hline
\end{tabular}




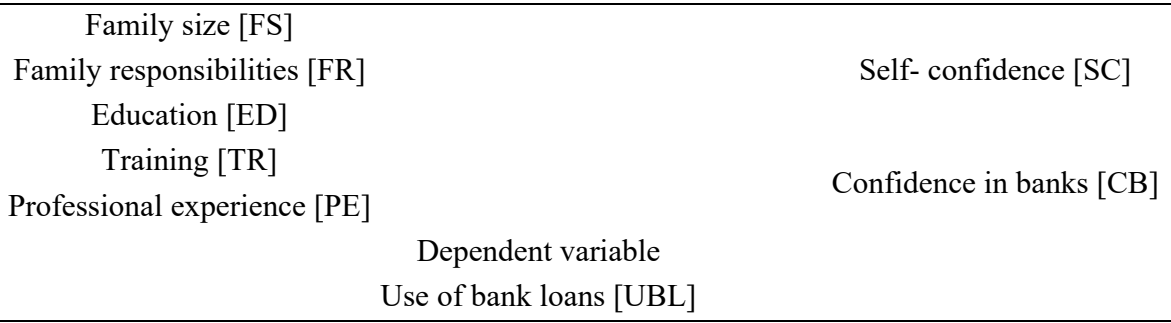

The binary scale is applied for the dependent variable [UBL] and variables concerning the Marital Status [MS], the Family Responsibilities [FR] and the Training Support [TS]. All other variables are coded using 5 Likert Scale.

\subsection{Data Sources and Sample Determination}

This study is conducted among women entrepreneurs managing different SMEs in ten Middle East and ten Western Europe countries. Given the difficulties associated with reaching to the sample of women entrepreneurs, the data collection was conducted through different steps.

In a first step, the population of women entrepreneurs was gathered from a secondary data. Multiple E-sources, reports and interviews are mobilized to identify some important elements of the profile of women entrepreneurs (the full name, the type of business activity and the number of employees). Two principal samples were composed respectively of 212 and 201 women entrepreneurs working in Middle East and Western Europe countries.

The second step consists of finding a way to contact each woman entrepreneur, through Facebook, Instagram or E-mail accounts. After many trials, the contacts of respectively 175 and 123 women entrepreneurs in the Middle East and the Western Europe are identified (Table 1, step 2, appendix 1). So, the questionnaire was sent to all women entrepreneurs with identified contacts and the respondent's rates had reached $22.86 \%$ for Middle East and $29.27 \%$ for Western Europe countries.

The final step consists of sending a reminder to all non-respondents'. Consequently, the respondent's rate had increased and reached $26.86 \%$ for the Middle East and $37.4 \%$ for the Western Europe. In total, the sample of the study was composed by 47 women entrepreneurs in Middle East and 46 in Western Europe (Table 3).

Table 3. Sample description

\begin{tabular}{|c|c|c|c|c|c|c|c|c|c|c|c|}
\hline Middle East & Bahrain & Cyprus & Jordan & Kuwait & Lebanon & Oman & Qatar & $\begin{array}{c}\text { Saudi } \\
\text { Arabia }\end{array}$ & UAE & Yemen & Total \\
\hline $\mathrm{N}$ & 5 & 6 & 2 & 4 & 8 & 2 & 5 & 6 & 7 & 2 & 47 \\
\hline $\begin{array}{l}\text { Western } \\
\text { Europe }\end{array}$ & Belgium & France & Germany & Greece & Ireland & Italy & Luxembourg & Portugal & Spain & UK & Total \\
\hline $\mathrm{N}$ & 4 & 6 & 2 & 7 & 5 & 4 & 3 & 3 & 6 & 6 & 46 \\
\hline
\end{tabular}

Note: N: number of women entrepreneurs operating in SME service activity that had replied on the questionnaire.

\section{Results and Analysis}

The data collected through the close ended questionnaire was analyzed below by descriptive statistics (4.1) and regression analysis (4.2).

\subsection{Descriptive Results}

The descriptive analysis presents the socio-demographic profile of women entrepreneurs (4.1.1) and their use of banks loans (4.1.2) in the Middle East and the Western Europe countries.

\subsubsection{Socio-Demographic Profile of Women Entrepreneurs}

The socio- demographic profile presents the main characteristics of women entrepreneurs. The main variables are age, marital status, family size, family responsibilities, education level, training support and professional previous experiences.

\section{Age of women entrepreneurs}

As shown in figure 2, the majority of women entrepreneurs in Middle East and Western Europe samples are between 26 and 31 years old. However, the lowest percentage is for the category of younger women entrepreneurs. For the Middle East, only 1\% of the respondents are between 20 and 25 years and the youngest 
woman entrepreneur has 23 years. For the Western Europe, it represents $4 \%$ of the respondents and the youngest woman entrepreneur has 21 years old (Note 3).

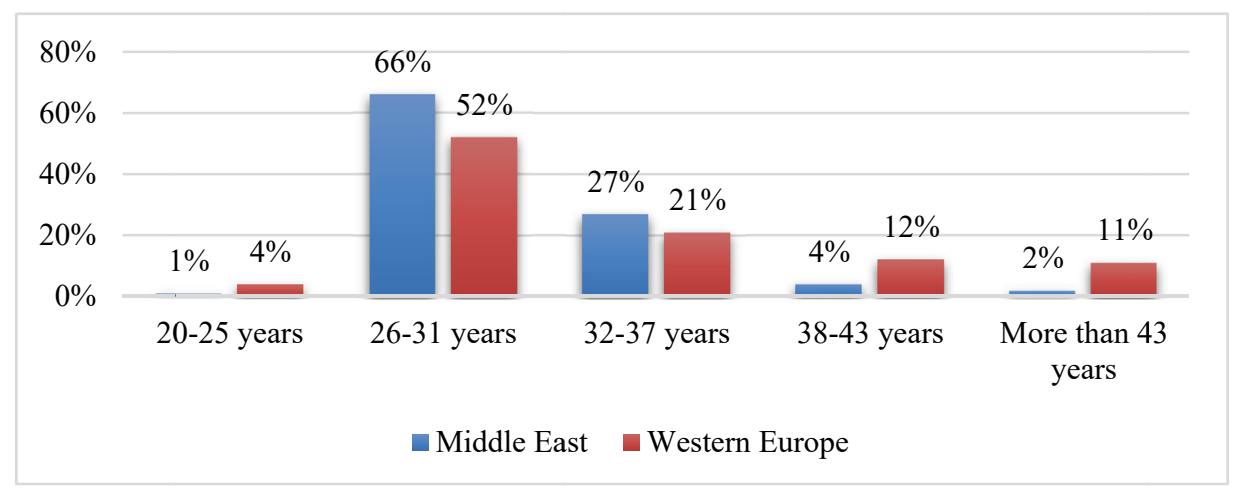

Figure 2. Age of women entrepreneurs

\section{Marital status}

Figure 3 shows that the majority of the respondents are married. The percentage of married women entrepreneurs represents $92 \%$ of the sample obtained from the Middle East region. However, the percentage of married women entrepreneurs decreases to $64 \%$ of the sample representing the Western Europe countries. Chamlou and Karshenas (2016) have also noticed that $85.4 \%$ of women entrepreneurs in the Middle East are married. These results indicate that married women entrepreneurs are more motivated to be involved in entrepreneurship process.

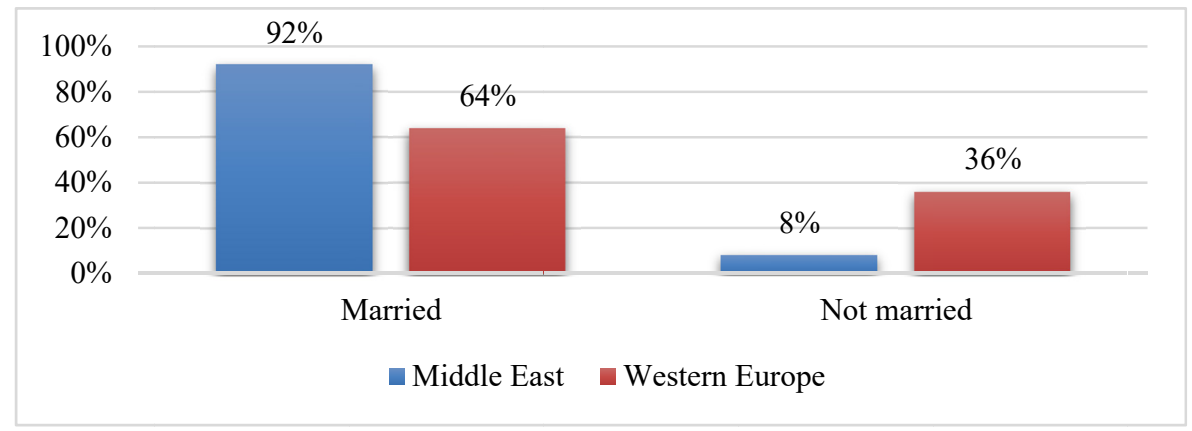

Figure 3. Marital status of women entrepreneurs

\section{Family size of women entrepreneurs}

Figure 4 shows that $77 \%$ of the respondents in the Middle East sample have 2 to 3 children, $16 \%$ of them have only 1 child, $3 \%$ have 4 children and $4 \%$ reported that they have no children. For the Western Europe, $41 \%$ of women entrepreneurs have one child and 37\% don't have children. However, women entrepreneurs with 2 to 3 children represent $22 \%$ of the Western Europe sample. Thus, the percentage of women entrepreneurs with more developed family exists in Middle East region. The demographic distribution of each region has its impact on the studied samples.

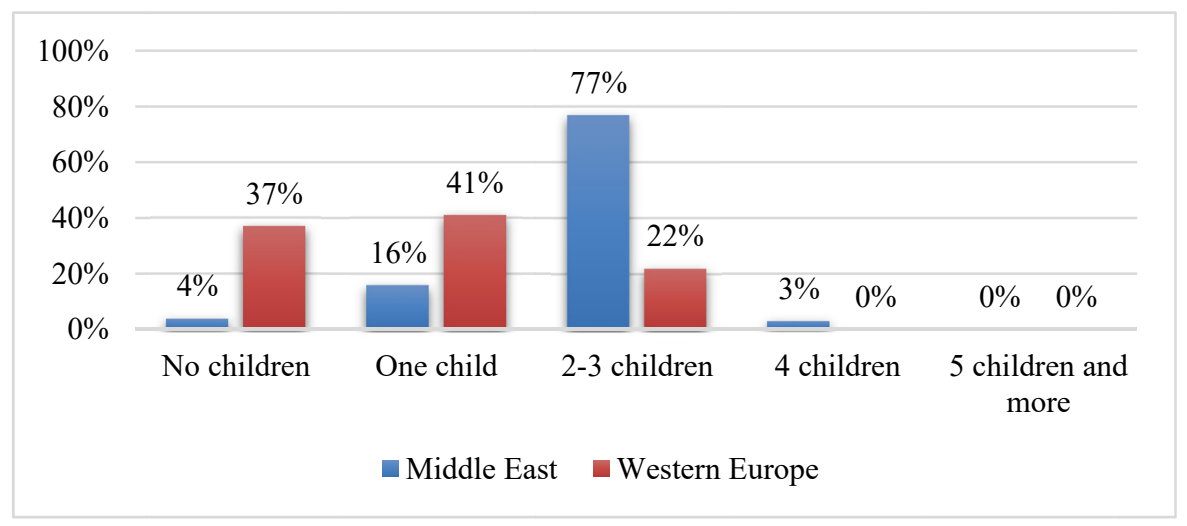

Figure 4. Family size of women entrepreneurs 


\section{Family responsibilities}

According to Figure 5, 81\% of women entrepreneurs fulfill their traditional role as being responsible of their childcare duties in the Middle East. For the Western Europe sample, 58\% of the respondents support this responsibility. Thus, women entrepreneurs in the Middle East experience much more pressure from the conflict between their entrepreneurial duties and childcare responsibilities than do their counterparts in the Western Europe region. However, this conflict may be partially resolved in the Middle East. Chamlou and Karshenas (2016) argued that women entrepreneurs in Middle East region receive important support from their mothers.

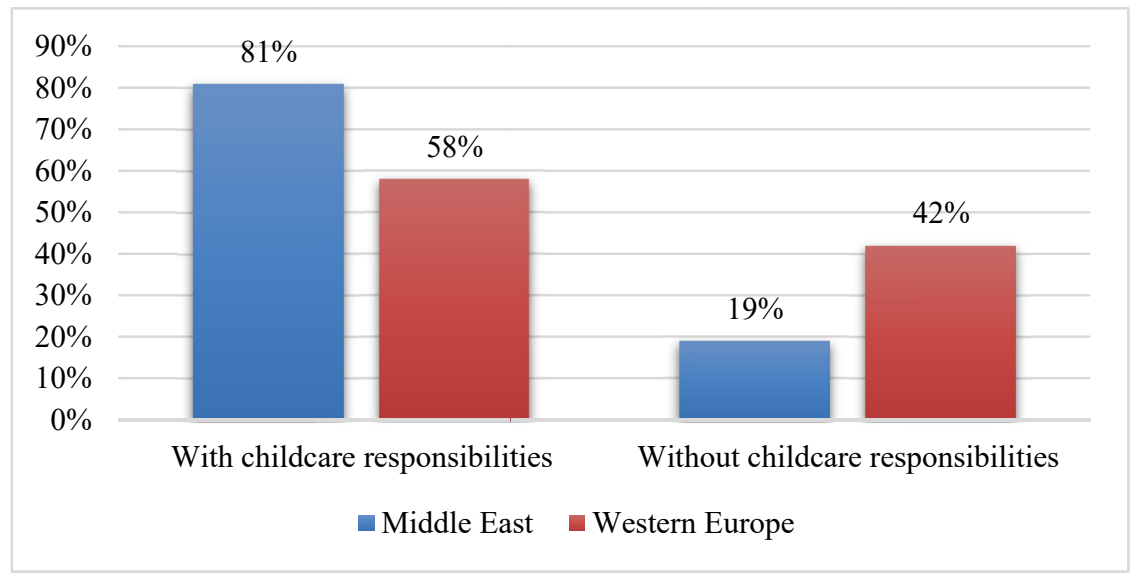

Figure 5. Family responsibilities of women entrepreneurs

\section{Education level of women entrepreneurs}

The majority of women entrepreneurs surveyed have a high level of education. As shown in figure $6,97 \%$ have a university degree in the Middle East. 51\% have a BA degree, 44\% have a Master's degree and 2\% have a PHD and plus degree. It is not a surprising result since women entrepreneurs have almost the same level of men's education in some countries, such as Lebanon (GEM, 2016) (Note 4) and Turkey (Özar, 2016). According to the Global Female Leaders (2019), the global percentage of educated youth women in the Middle East is $91.5 \%$ (Note 5). For the Western Europe sample, 99\% of the respondents have a university degree. The level of education varies as follow: 49\% for BA degree, $47 \%$ for Master's degree and 3\% for PHD and plus degree. This result demonstrates that women entrepreneurs are very well educated. Higher education theoretically offers them more skills that can be used in their business (Note 6).

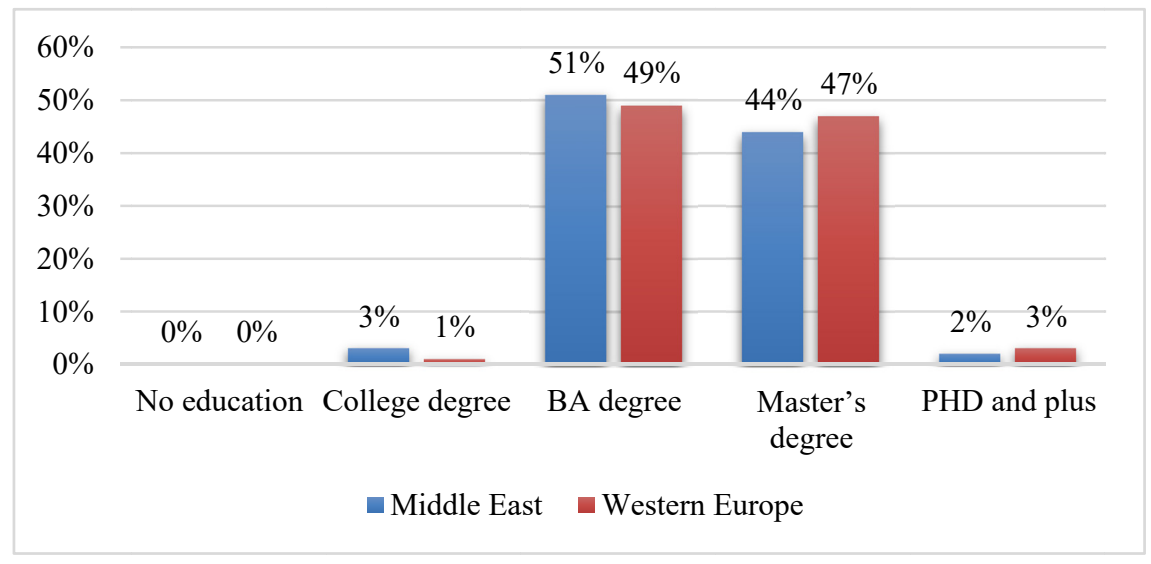

Figure 6. Education level of women entrepreneurs

\section{Training of women entrepreneurs}

As shown in Figure 7, respectively $94 \%$ and $98 \%$ of the respondents in the Middle East and the Western Europe samples have already received a training support. This result indicates that in the Middle East and the Western Europe regions, the ecosystem is well established and offers the needed support to motivate women entrepreneurs to be involved in the entrepreneurship process. 


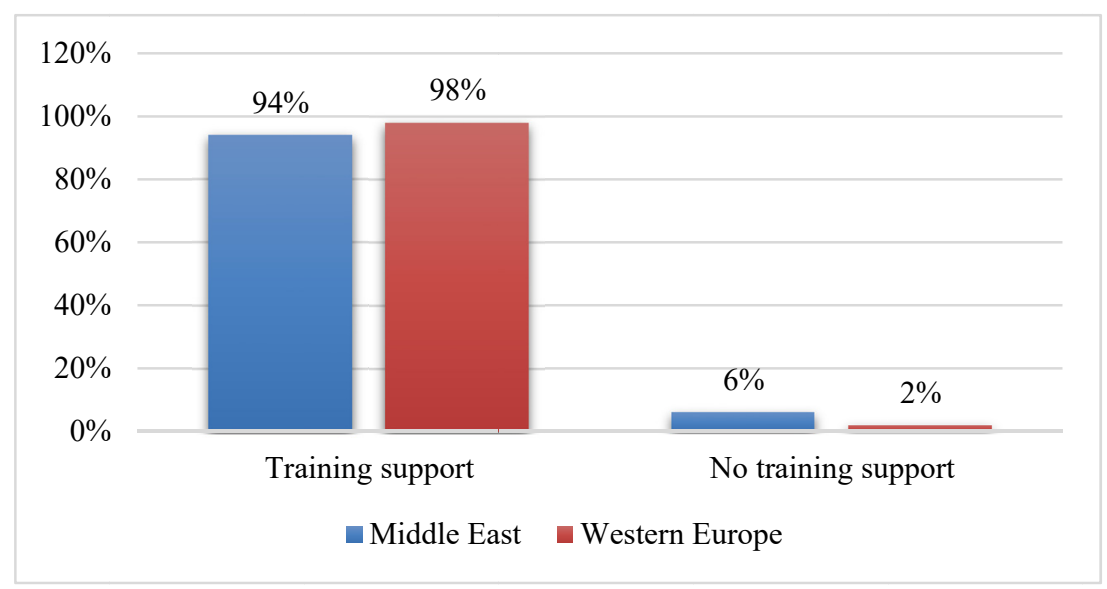

Figure 7. Training support of women entrepreneurs

\section{Professional experiences of women entrepreneurs}

Figure 8 illustrates that $51 \%$ of the respondents in the Middle East have 4 to 7 years of experience, $24 \%$ of them have 2 to 3 years of experience and $22 \%$ have 8 to 10 years. It means that almost the majority of women entrepreneurs in Middle East have an experience before being a part of the entrepreneurship process. This result is confirmed by the IFC and CAWTAR (2015) (Note 7) surveys because women entrepreneurs in the MENA region were found to have extensive years of experience (Note 8). For the Western Europe sample, $63 \%$ of the respondents have 2 to 7 years of experience. Only $9 \%$ of them have an experience of more than 10 years and $2 \%$ with 1 year of experience. Thus, women entrepreneurs in the Middle East and the Western Europe accumulate important experience. Bouzekraoui and Ferhane (2014) consider that professional experience is a stepping stone for women entrepreneurship and usually women create companies linked to their previous experience.

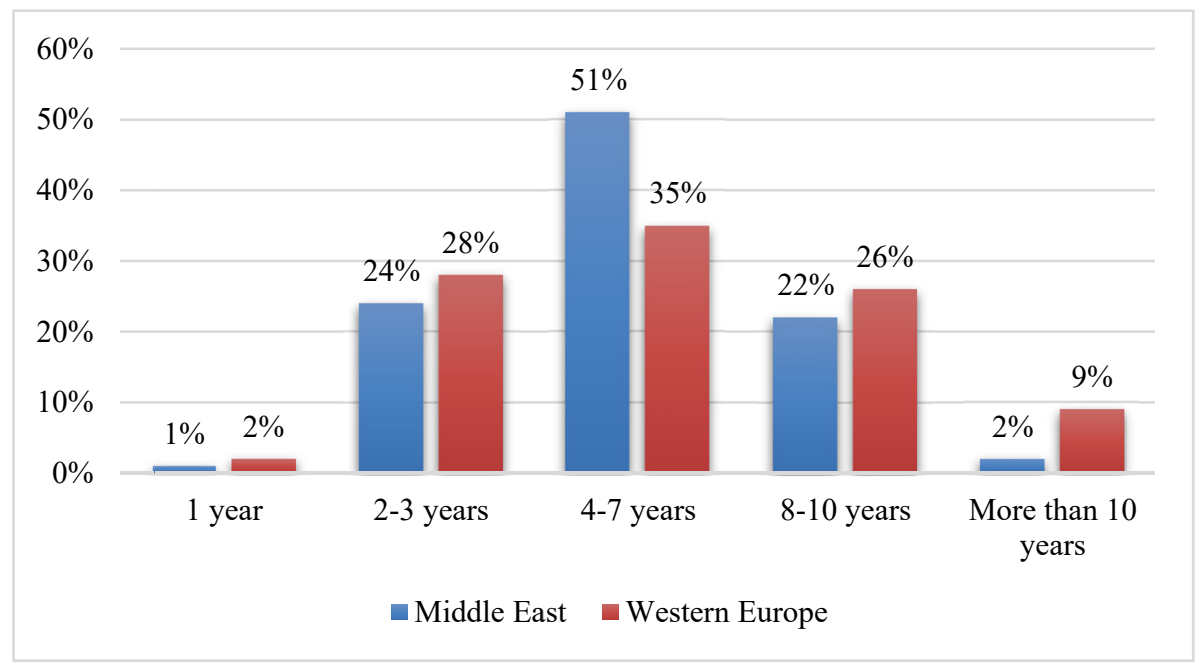

Figure 8. Professional experiences of women entrepreneurs

\subsubsection{Referring to Bank Loans}

As shown in Figure 9, only $26 \%$ of women entrepreneurs in the Middle East and $31 \%$ of women entrepreneurs in the Western Europe countries have used bank loans. According to literature, women entrepreneurs have less growth aspirations and tend to go through small and medium projects (Heidrick \& Nicol, 2002; Orhan, 2001). Also, women entrepreneurs are considered to have fear of loans (Alam et al., 2011), lack of confidence in themselves (Peni \& Vahamaa, 2010) and lack of confidence in financial institutions (Fabowale et al., 1995). From another point of view, banks consider that lending to women entrepreneurs is unsecure. Thus, they fix more restrictive and unfavorable lending conditions for them (Belluchi et al., 2010; Kwong et al., 2012). 


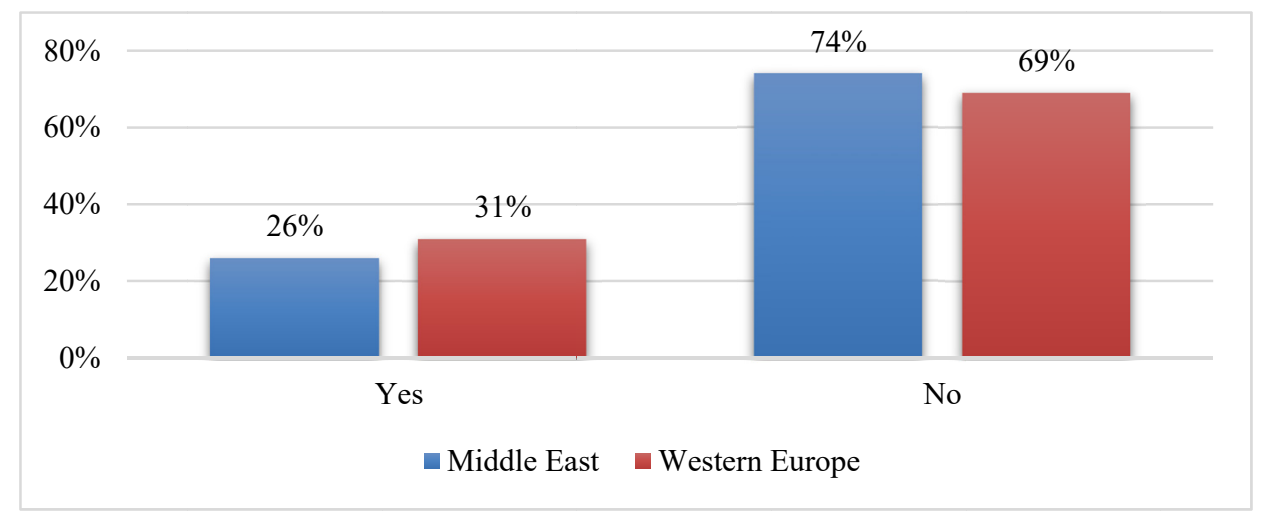

Figure 9. Referring to bank loans by women entrepreneurs

\subsection{Regression Analysis}

The regression analysis defines the explanatory power of each selected variable. The dependent variable is the Use of Bank Loans [UBL], a dummy variable (0/1), equal to 1 if the respondent has used a bank loan. In order to measure the independent variables two type of scale were used: the Likert scale with five-point scale (from 1 to 5 ) and the binary scale (1/0). Variables concerning the Marital Status [MS], the Family Responsibilities [FR] and the Training Support [TS] were coded using the binary scale (1/0). The Likert scale was employed for all other variables. The regression model is presented below and the results are shown in the following table.

Table 3. Results of the UBL regression models

\begin{tabular}{|c|c|c|c|c|}
\hline & \multicolumn{4}{|c|}{ Dependent variable: UBL } \\
\hline & \multicolumn{2}{|l|}{ Middle East } & \multicolumn{2}{|l|}{ Western Europe } \\
\hline & Standardized Coefficients & \multirow{2}{*}{ Sig. } & Standardized Coefficients & \multirow{2}{*}{ Sig. } \\
\hline & Beta & & Beta & \\
\hline (Constant) & 41.671 & $.001 * * *$ & 38.229 & $.003 * * *$ \\
\hline \multicolumn{5}{|c|}{ Socio-demographic profile variables } \\
\hline AGW & .448 & $.000 * * *$ & .396 & $.000 * * *$ \\
\hline MS & -.178 & $.005 * * *$ & -.129 & $.049 * *$ \\
\hline FS & -.211 & $.001 * *$ & -.206 & $.007 * *$ \\
\hline FR & -.384 & $.000 * * *$ & -.372 & $.000 * * *$ \\
\hline $\mathrm{ED}$ & .017 & .239 & .092 & $.068^{*}$ \\
\hline TR & .044 & .282 & .126 & $.071^{*}$ \\
\hline $\mathrm{PE}$ & .178 & $.005^{* * *}$ & .159 & $.024 * * *$ \\
\hline \multicolumn{5}{|c|}{ Subjective perception variables } \\
\hline RT & -.654 & $.000 * * *$ & -.599 & $.000 * * *$ \\
\hline $\mathrm{SC}$ & -.377 & $.000 * * *$ & -.083 & $.079 *$ \\
\hline $\mathrm{CB}$ & -.211 & $.000 * * *$ & -.131 & $.035 * *$ \\
\hline R-square & \multicolumn{2}{|l|}{$66.9 \%$} & \multicolumn{2}{|l|}{$65.1 \%$} \\
\hline Adjusted R-square & \multicolumn{2}{|l|}{$64.7 \%$} & \multicolumn{2}{|l|}{$62.3 \%$} \\
\hline F statistic & \multicolumn{2}{|l|}{33.864} & \multicolumn{2}{|l|}{32.089} \\
\hline Model significance P-value & \multicolumn{2}{|l|}{.000} & \multicolumn{2}{|l|}{.000} \\
\hline
\end{tabular}

Note: [AGW]: Age of women entrepreneurs, [MS]: Marital status, [FS]: Family size, [FR]: Family responsibilities, [ED]: Education level, [TR]: Training support, [PE]: Professional experience, [RT]: Risk tolerance, [SC]: Self- confidence, [CB]: Confidence in banks, [UBL]: Use of bank loans

Table 3 reveals that the regression model applied is highly significant since P-value is equal to 0.000 for both selected regions. The Adjusted R-squares are respectively $64.7 \%$ and $62.3 \%$ for the Middle East and the Western Europe. This means that the designated variables explain $64.7 \%$ of the use of bank loans by women entrepreneurs in the Middle East and $62.3 \%$ in the Western Europe. According to beta coefficients, the use of bank loans is fundamentally dependent of the socio-demographic profile and the subjective perception of women 
entrepreneurs.

As for the socio-demographic profile, the age of women entrepreneurs provides a positive and a high significant impact (at 1\% level of significance) on the use of bank loans. Beta coefficients of AGW are respectively equal to 0.448 and 0.396 for the Middle East and the Western Europe. This result explains that women entrepreneurs in both regions accumulate important experience with age increasing, which lead them to support conditions and risk derived from bank loans.

The marital status [MS] of women entrepreneurs presents a negative and significant impact on the use of bank loans at the levels of $1 \%$ for the Middle East and $5 \%$ for the Western Europe. Also, the family size [FS] shows a negative and significant impact on the use of bank loans. Beta coefficient of [FS] is -0.211 for Middle East and -0.206 for Western Europe at $5 \%$ level of significance. Family responsibilities [FR] also has a negative and significant impact at $1 \%$ level of significance. Beta coefficients of [FR] are equal to -0.384 for Middle East and -0.372 for Western Europe. These results indicate that married women entrepreneurs in Middle East and Western Europe countries seek to balance the business activity with the family responsibilities. These results are in line with the findings of Weber (2013) and St-Cyr (2002), childcare and family responsibilities increase women entrepreneurs risk aversion. In consequence, they avoid request for bank credits.

However, Alsos et al. (2016) found that women entrepreneurs adopt some specific strategies to cope with this challenge because families with young children have other needs than families with adolescence or families with adults. Özar (2016) discovered that women entrepreneurs feel that their family duties, especially those related to childcare responsibilities poses the worst constraint on their business. Accordingly, financing decisions of women entrepreneurs in Middle East and Western Europe countries are influenced by their family issues. Results of this study confirm that marital status, family size and family responsibilities of women entrepreneurs play a negative and significant role on their willingness of using debt financing.

The education level [ED] and training support [TR] show positive and significant impact on the use of bank loans by women entrepreneurs in Western Europe at $10 \%$ level of significance. Beta coefficients are equal to 0.092 for [ED] and 0.126 for [TR]. In fact, literature have demonstrated that women entrepreneurs require a business training to develop the core skills and competence that they need to be successful in their entrepreneurial activity. Most of them are interested in attending to external training and support services, believing that it would be helpful in managing the growth of their activities. Also, studies of the entrepreneurship have confirmed that education and training motivate women entrepreneurs to support a higher level of risk and recognize more access to bank loans (Knight et al., 2003; Coleman, 2004; Fairlie \& Holleran, 2012). The result of this study confirms these findings for the Western Europe region. However, education level and training support of women entrepreneurs in the Middle East region have showed a positive but non-significant impact on the use of bank loans.

The professional experience [PE] affects positively the use of bank loans by women entrepreneurs in the Middle East and the Western Europe countries. Beta coefficients are 0.178 for Middle East and 0.159 for Western Europe, with $1 \%$ level of significance. This result confirms literature findings by considering that the experience of women entrepreneurs plays an important role on their financing choices. Accordingly, the low experience of women entrepreneurs causes barriers on their access to bank loans (Dahalan et al., 2013; Roomi et al., 2009; St-Cyr, 2002; Danmanville \& Hurel, 2001). It makes women entrepreneurs feel insecure during financial negotiations. Therefore, bankers consider that women entrepreneurs have an insufficient experience and reject their loans applications (Haines et al., 1999).

Furthermore, regression results confirm that the subjective perception variables provide an explanation about the attitude of women entrepreneurs towards the use of bank loans. Beta coefficients of the risk tolerance variable [RT] are equal to -0.654 for Middle East and -0.599 for Western Europe at $1 \%$ level of significance. The same results have been observed by Bardasi et al. (2011), Huang and Kisgen (2013) and Faccio et al. (2015), who indicate that the risk tolerance of women entrepreneurs in the Middle East and the Western Europe countries affects negatively on their use of bank loans. Women entrepreneurs try to avoid supporting financial risks by avoiding debts financial sources.

The self-confidence variable [SC] of women entrepreneurs presents also a negative impact on the use of bank loans at the levels of $1 \%$ significance for the Middle East and $10 \%$ for the Western Europe. Beta coefficients are equal to -0.377 for the Middle East and -0.083 for the Western Europe. This result supports the literature findings of Becker-Blease and Sohl (2011), Barua et al. (2010) and Peni and Vahamaa (2010). It shows that women entrepreneurs in the Middle East and the Western Europe countries prefer not to be involved in bank loans issues due to of their lack of confidence. 
Finally, women entrepreneurs are found to be not comfortable with banks. The confidence of women entrepreneurs towards banks [CB] shows a negative ( -0.211 for Middle East and -0.131 for Western Europe) and significant impact on the use of bank loans. The results confirm the findings of Constantinidis et al. (2006) who reveal that women entrepreneurs in Middle East and Western Europe have a negative perception towards bank loans. They prefer financial resources coming from trusted sources, as family and friends (Brindley, 2005; Wolken, 2002; St-Cyr, 2002).

\section{Discussion}

Women entrepreneurs reveal a significant importance for researches in entrepreneurship domain. Recently, studies have revealed that women entrepreneurs have their specific personal profile and individual factors that could affect their personal orientations. According to literature, empirical investigations have tried to provide evidence on this topic by selecting a sample of one single country, or two different countries, or a cross-country sample. Based on this fact, this research is unique because it aims to present the profile of women entrepreneurs and to analyze the impact of their individual factors on their use for bank loans by selecting an unexplored cross-country sample.

Accordingly, this article focuses on presenting the profile of women entrepreneurs and testing how their socio-demographic and subjective perception characteristics could affect their preference for bank loans in the Middle East and the Western Europe countries. The sample was composed of 47 and 46 women entrepreneurs operating in small and medium (SME) business in ten Middle East and ten Western Europe countries respectively. Descriptive results show that the majority of women entrepreneurs are between 26 and 31 years old. Women entrepreneurs with more developed family exists in Middle East region. Thus, they support more pressure than do their counterparts in Western Europe and they face more conflict between their entrepreneurial duties and childcare responsibilities.

The majority of women entrepreneurs have a high level of education. Almost, $97 \%$ of them in the Middle East and $99 \%$ in Western Europe have a university degree. Additionally, they have already received a training support to help them in their entrepreneurship activity and found to have accumulate an important professional experience. Furthermore, results show that women entrepreneurs avoid referring to banks' financial resources. Only $26 \%$ of them in the Middle East and $31 \%$ in the Western Europe have already used bank loans.

The above results are analyzed and explained by the regression outputs. First, the socio-demographic profile of women entrepreneurs affects significantly on their use of bank loans. The age, the education level, the training support and the professional experience of women entrepreneurs provide a positive and high significant impact on their use of bank loans for both regions, Middle East and Western Europe. But, the marital status and all the family issues; such as family size and family responsibilities; affect negatively on their willingness of using debt financing. Second, all variables related to the subjective perception of women entrepreneurs present a negative and significant impact on their use of bank loans in Middle East and Western Europe countries. Women entrepreneurs prefer to avoid bank loans due to of their risk tolerance, their lack of confidence and their lack of confidence towards banks. Finally, this research is at very early stage so lot of work remains to be done in future. But, it will motivate for more studies in this domain and will contribute for banks and for women entrepreneurs.

\section{References}

Adhikary, M. M., Pradhan, K., \& Saharia, R. (2011). Analysing the risk orientation of cane and bamboo handicraft entrepreneurs with respect to their socio- economic correlates in Assam. Journal of Crop and Weed, 7(2), 217-219.

Alam, S. S., Jani, M. F. M., \& Omar, N. A. (2011). An empirical study of success factors of women entrepreneurs in southern region in Malaysia. International Journal of Economics and Finance, 3(2), 166-175. https://doi.org/10.5539/ijef.v3n2p166

Alsos, G. A., Carter, S., Ljunggren, E., \& Jørstad, M. O. (2016). Women, Family and Entrepreneurship: Strategies for Managing Work-life Balance Challenges. Academy of Management Proceedings, 16(1), 78-99. https://doi.org/10.5465/ambpp.2016.16079abstract

Ansari, D. A. (2016). Women Entrepreneurship in India. AEIJST, 4(4), 2348-6732.

Au, K., Chiang, F. F. T., Birtch, T. A., \& Ding, Z. (2013). Incubating the next generation to venture: The case of a family business in Hong Kong. Asia Pacific Journal of Management, 30(3), 749-767. https://doi.org/10.1007/s10490-012-9331-7

Au, L., \& Kwan, H. K. (2009). Start-up capital and Chinese entrepreneurs: The role of family. Entrepreneurship 
Theory and Practice, 33(4), 889-908. https://doi.org/10.1111/j.1540-6520.2009.00331.x

Bardasi, E., Sabarwal, S., \& Terrell, K. (2011). How do female entrepreneurs perform? Evidence from three developing regions. Small Business Economics, 37(4), 417-441. https://doi.org/10.1007/s11187-011-9374-z

Barua, A., Davidson, L. F., Rama, D. V., \& Thiruvadi, S. (2010). CFO Gender and Accruals Quality. Accounting Horizons, 24(1), 25-39. https://doi.org/10.2308/acch.2010.24.1.25

Becker-Blease, J., \& Sohl, J. (2011). The effect of gender diversity on angel group investment. Entrepreneurship Theory and Practice, 35(4), 709-733. https://doi.org/10.1111/j.1540-6520.2010.00391.x

Belluchi, A., Borisov, A., \& Zazzaro, A. (2010). Does gender matter in bank-firm relationships? Evidence from small business lending. Journal of Banking and Finance, 34(12), 2968-2984. https://doi.org/10.1016/j.jbankfin.2010.07.008

Bengtsson, C., Persson, M., \& Willehag, P. (2004). Gender and overconfidence. Economics Letters, 86, 199-203. https://doi.org/10.1016/j.econlet.2004.07.012

Bird, B., \& Brush, C. (2002). A gendered perspective on organizational creation. Entrepreneurship Theory and Practice, 26(3), 41-65. https://doi.org/10.1177/104225870202600303

Blunch, N. H., Canagarajah, S., \& Raju, D. (2001). The informal sector revisited: A synthesis across space and time. Social Protection Discussion, paper 0119, Social Protection Unit, Human Development Network, World Bank, Washington, DC.

Boden, R. J., \& Nucci, A. R. (2000). On the survival prospects of men's and women's new business ventures. Journal of Business Venturing, 15(4), 347-362. https://doi.org/10.1016/S0883-9026(98)00004-4

Borghans, L., Golsteyn, B. H. H., Heckman, J., \& Meijers, H. H. M. (2009). Gender differences in risk aversion and ambiguity aversion. Journal of the European Economic Association, 7(2), 649-658. https://doi.org/10.1162/JEEA.2009.7.2-3.649

Bortamuly, A. B., Goswami, K., Hazarika, B., \& Handique, K. (2014). Do different determinants affect differently across gender and location in handloom entrepreneurship development? Journal of Small Business \& Entrepreneurship, 27(5), 61-83. https://doi.org/10.1080/08276331.2015.1088298

Bouzekraoui, H., \& Ferhane, D. (2014). Les obstacles au développement de l'entrepreneuriat féminin au maroc. XXXème journées du développement ATM 2014. Colloque international sur l'éthique, l'entrepreneuriat et le développement. University Cadi Ayad Marrakech. Les 29, 30 et 31 mai 2014.

Brauw, A., \& Eozenou, P. (2014). Measuring risk attitudes among Mozambican farmers. Journal of Development Economics, 111, 61-74. https://doi.org/10.1016/j.jdeveco.2014.08.002

Brindley, C. (2005). Barriers to women achieving their entrepreneurial potential: Women and risk. International Journal of Entrepreneurial Behavior \& Research, 11(2), 144-161. https://doi.org/10.1108/13552550510590554

Brush, C. G., De Bruin, A., \& Welter, F. (2009). A gender-aware framework for women's entrepreneurship. $\begin{array}{lllll}\text { International Journal of Gender and Entrepreneurship, } & 1(1), & \text { 8-24. }\end{array}$ https://doi.org/10.1108/17566260910942318

Buttner, E. H., \& Rosen, B. (1992). Rejection in the loan application process: Male and female entrepreneurs' perceptions and subsequent intentions. Journal of Small Business Management, 30(1), 58-65.

Carter, S., \& Cannon, T. (1992). Women as entrepreneurs. London: Academic Press.

Carter, S., Shaw, E., Lam, W., \& Wilson, F. (2007). Gender, entrepreneurship, and bank lending: The criteria and processes used by bank loan officers in assessing applications. Entrepreneurship Theory and Practice, 31(3), 427-444. https://doi.org/10.1111/j.1540-6520.2007.00181.x

Castillo, M., \& Freer, M. (2018). Revealed differences. Journal of Economic Behavior \& Organization, 145, 202-217. https://doi.org/10.1016/j.jebo.2017.10.017

Castillo, M., Petrie, R., Cotla, C. R., \& Torero, M. (2017). Understanding the risk preferences of the poor. Working Paper.

Chaganti, R., DeCarolis, D., \& Deeds, D. (1995). Predictors of capital structure in small ventures. Entrepreneurship Theory and Practice, 20(2), 7-18. https://doi.org/10.1177/104225879602000202

Chamlou, N., \& Karshenas, M. (2016). Women, Work and Welfare in the Middle East and North Africa: The Role 
of Socio-demographics, Entrepreneurship and Public Policies. London: Imperial College Press. https://doi.org/10.1142/p1017

Coleman, S. (2004). Access to debt capital for women- and minority-owned small firms: Does educational attainment have an impact? Journal of Developmental Entrepreneurship, 9(2), 127-143.

Collins, J., \& Low, A. (2010). Asian female immigrant entrepreneurs in small and medium- sized businesses in Australia. Entrepreneurship \& Regional Development, 22(1), 97-111. https://doi.org/10.1080/08985620903220553

Constantinidis, C., Cornet, A., \& Asandei, S. (2006). Financing of women-owned ventures: The impact of gender and other owner-and firm-related variables. Venture Capital, 8(2), 133-157. https://doi.org/10.1080/13691060600572557

Croson, R., \& Gneezy, U. (2009). Gender Differences in Preferences. Journal of Economic Literature, 47(2), 448-474. https://doi.org/10.1257/jel.47.2.448

Dahalan, N., Jaafar, M., \& Rosdi, S. A. M. (2013). Local community readiness in entrepreneurship: Do gender differ in searching business opportunity. Procedia - Social and Behavioral Sciences, 91, 403-410. https://doi.org/10.1016/j.sbspro.2013.08.437

Danish, A. Y., \& Smith, H. L. (2012). Female entrepreneurship in Saudi Arabia: Opportunities and challenges. International Journal of Gender and Entrepreneurship, 4(3), 216-235. https://doi.org/10.1108/17566261211264136

Danmanville, P., \& Hurel, F. (2001). Les femmes et la création d'entreprise. Agence Pour la Création d'Entreprises, Collection Focus.

Diane, H. B., Memili, E., Kaciak, E., \& Al-Sadoon, A. (2014). Saudi women entrepreneurs: A growing economic segment. Journal of Business Research, 67, 758-762. https://doi.org/10.1016/j.jbusres.2013.11.040

Dittrich, D., Werner, G., \& Maciejovsky, B. (2001). Overconfidence in Investment Decisions: An Experimental Approach. CESifo Working Paper, No. 626, Center for Economic Studies and Ifo Institute (CESifo), Munich.

Dwyer, P., Gilkenson, J., \& List, J. (2002). Gender differences in revealed risk taking: Evidence from mutual fund investors. Economic Letters, 76, 151-158. https://doi.org/10.1016/S0165-1765(02)00045-9

Eckel, C. C., \& Grossman, P. J. (2008). Differences in the economic decisions of men and women: Experimental evidence. Handbook of Experimental Economics Results, 1(57), 509-519. https://doi.org/10.1016/S1574-0722(07)00057-1

Fabowale, L., Orser, B., \& Riding, A. (1995). Gender, structural factors, and credit terms between Canadian small businesses and financial institutions. Entrepreneurship Theory and Practice, 19(4), 41-66. https://doi.org/10.1177/104225879501900404

Faccio, M., Marchica, M., \& Mura, R. (2015). CEO Gender, Corporate Risk-Taking, and the Efficiency of Capital Allocation. Working paper. https://doi.org/10.1016/j.jcorpfin.2016.02.008

Fairlie, R. W., \& Holleran, W. (2012). Entrepreneurship training, risk aversion and other personality traits: Evidence from a random experiment. Journal of Economic Psychology, 33(2), 366-378. https://doi.org/10.1016/j.joep.2011.02.001

Filser, M., Eggers, F., Kraus, S., \& Málovics, E. (2014). The effect of financial resource availability on entrepreneurial orientation, customer orientation and firm performance in an international context: An empirical analysis from Austria and Hungary. Journal for East European Management Studies, 19(1), 7-30. https://doi.org/10.5771/0949-6181-2014-1-7

Global Entrepreneurship Monitor - GEM. (2016). Lebanese National Report: Lebanon. Retrieved from http://www.databank.com.lb/docs/Entrepreneurship\%20in\%202016-GEM-UKLTH.pdf

Gong, B., \& Yang, C. L. (2012). Gender differences in risk attitudes: Field experiments on the matrilineal Mosuo and the patriarchal Yi. Journal of Economic Behavior \& Organization, 83(1), 59-65. https://doi.org/10.1016/j.jebo.2011.06.010

Greene, P. G., Brush, C. G., Hart, M. M., \& Saparito, P. (2001). Patterns of venture capital funding: Is gender a factor? Venture Capital, 3(1), 63-83. https://doi.org/10.1080/136910601300050357

Grilo, I., \& Irigoyen, J. M. (2005). Entrepreneurship in the EU: To wish and not to be. Small Business Economics, 


\section{6, 305-318. https://doi.org/10.1007/s11187-005-1561-3}

Haines, G. H., Orser, B. J., \& Riding, A. L. (1999). Myths and realities: An empirical study of banks and the gender of small business clients. Revue Canadienne des Sciences de l'Administration, 16(4), 291-307. https://doi.org/10.1111/j.1936-4490.1999.tb00690.x

Hazarika, B., \& Goswami, K. (2014). Rural non-farm micro-entrepreneurship or not: Gender issue in decision making. Presented in 6th Bolivian Conference on Development Economics in Cochabamba, Bolivia, 28-29 August. https://doi.org/10.2139/ssrn.2598405

Heidrick, T., \& Nicol, T. (2002). Financing SMEs in Canada: Barriers faced by women, youth, Aboriginal and minority entrepreneurs in accessing capital. Phase 1: Literature review. Research Paper prepared for the Small Business Policy Branch as part of the Small and Medium-sized Enterprise (SME) Financing Data Initiative, Industry Canada, January.

Huang, J., \& Kisgen, D. J. (2013). Gender and corporate finance: Are male executives overconfident relative to female executives? Journal of Financial Economics, 108(3), 822-839. https://doi.org/10.1016/j.jfineco.2012.12.005

Hughes, K. D., Jennings, J. E., Brush, C., Carter, S., \& Welter, F. (2012). Extending women's entrepreneurship research in new directions. Entrepreneurship theory and practice, 36(3), 429-442. https://doi.org/10.1111/j.1540-6520.2012.00504.x

Hussain, S., Nayab, H., Shahzad, F., Fareed, Z., \& Ul-Abidan, Z. (2014). An empirical investigation of entrepreneurial intentions among business students in Pakistan. Studia Universitatis Babes-Bolyai Oeconomica, 59(2), 167-198.

Iakovleva, T., Solesvik, M., \& Trifilova, A. (2013). Financial availability and government support for women entrepreneurs in transitional economies. Journal of Small Business and Enterprise Development, 20(2), 314-340. https://doi.org/10.1108/14626001311326752

Ivanova Yordanova, D., \& Ivanova Alexandrova-Boshnakova, M. (2011). Gender effects on risk-taking of entrepreneurs: Evidence from Bulgaria. International Journal of Entrepreneurial Behavior \& Research, 17(3), 272-295. https://doi.org/10.1108/13552551111130718

Johan, M., Leroy, H., \& Sels, L. (2013). Gender differences in entrepreneurial intentions: A TPB multi- group analysis at factor and indicator level. European Management Journal, 32(5), 784-794. https://doi.org/10.1016/j.emj.2014.01.001

José, L. M. M., Del Mar Miralles-Quirós, M., \& Lisboa, I. (2014). The impact of family control on firm performance: Evidence from Portugal and Spain. Journal of Family Business Strategy, 5(2), 156-168. https://doi.org/10.1016/j.jfbs.2014.03.002

Kepler, E., \& Shane, S. (2007). Are Male and Female Entrepreneurs Really That Different? Small Business Research Summary, (309), 61-85.

Khalife, D., \& Chalouhi, A. (2013). Gender and business performance. International Strategic Management Review, 1, 1-10. https://doi.org/10.1016/j.ism.2013.08.001

Klonowski, D. (2010). The effectiveness of government-sponsored programs in supporting the SME sector in Poland. Post-Communist Economics, 22(2), 229-245. https://doi.org/10.1080/14631371003740738

Knight, J., Weir, S., \& Woldehanna, T. (2003). The role of education in facilitating risk-taking and innovation in agriculture. Journal of Development Studies, 39(6), 1-22. https://doi.org/10.1080/00220380312331293567

Kobeissi, N. (2010). Gender factors and female entrepreneurship: International evidence and policy implications. Journal of International Entrepreneurship, (8), 1-35. https://doi.org/10.1007/s10843-010-0045-y

Kwong, C., Jones-Evans, D., \& Thompson, P. (2012). Differences in perception pf access to finance between potential male and female entrepreneurs' evidence from the UK. International Journal of Entrepreneurial Behavior and Research, 18(1), 75-97. https://doi.org/10.1108/13552551211201385

Levesque, M., \& Minniti, M. (2006). The effect of aging on entrepreneurial behavior. Journal of Business Venturing, 21(2), 177-194. https://doi.org/10.1016/j.jbusvent.2005.04.003

Lituchy, T., \& Reavley, M. (2004). Women Entrepreneurs: A Comparison of International Small Business Owners in Poland and the Czech Republic: Special Issue on International Entrepreneurship in a Dynamic Complex Open Adaptive System. Journal of International Entrepreneurship, 2(1/2), 189-205. 
https://doi.org/10.1023/B:JIEN.0000026906.28190.df

Mohd Shariff, N. (2009). Women's Business Ownership: A Review of the Academic, Popular and Internet Literature. Journal of International Entrepreneurship, 6(2), 234-250.

Muravyev, A., Talavera, O., \& Schafer, D. (2009). Entrepreneurs' gender and financial constraints: Evidence from international data. J. Comp. Econ. 37(2), 270-286. https://doi.org/10.1016/j.jce.2008.12.001

Muravyev, A., Talavera, O., \& Schäfer, D. (2007). Entrepreneurs Gender and Financial Constraints: Evidence from International data. Discussion Papers 706, German Institute for Economic Research, 1-35.

Neelakantan, U. (2010). Estimation and impact of gender differences in risk tolerance. Economic Inquiry, 48(1), 228-233. https://doi.org/10.1111/j.1465-7295.2009.00251.x

Noor, H. A., Nasurdin, A. M., Abdul Halim, H., \& Taghizadehd, S. K. (2014). The Pursuit of Entrepreneurial Initiatives at the "Silver" Age: From the Lens of Malaysian Silver Entrepreneurs. Procedia - Social and Behavioral Sciences, 129, 305-313. https://doi.org/10.1016/j.sbspro.2014.03.681

OECD (Organization for Economic Cooperation and Development). (2000). Background Report/ Workshop No. 3: Financing for women-owned business. From OECD Conference: Women Entrepreneurs in SMEs: Realizing the benefits of globalization and the knowledge-based economy, Paris, 29-30 November.

Ongena, S., \& Popov, A. (2013). Gender Bias and Credit Market Barriers for Female Entrepreneurs. Working Paper.

Orhan, M. (2001). Women business owners in France: The issue of financing discrimination. Journal of Small Business Management, 39(1), 95-102. https://doi.org/10.1111/0447-2778.00009

Özar, S. (2016). Women entrepreneurs in Turkey: Obstacles, Potentials and Prospects, in Women, Work and Welfare in the Middle East and North Africa. In N. Chamlou \& M. Karshenas (Eds.), The role of Sociodemographics, Entrepreneurship and Public policies (pp. 235-262). Imperial College Press. https://doi.org/10.1142/9781783267347_0009

Peni, E., \& Vähämaa, S. (2010). Female executives and earnings management. Managerial Finance, 36(7), 629-645. https://doi.org/10.1108/03074351011050343

Pérez-Pérez, C., \& Avilés-Hernández, M. (2016). Explanatory factors of female entrepreneurship and limiting elements. Suma De Negocios, 7, 25-31. https://doi.org/10.1016/j.sumneg.2015.12.004

Powell, M., \& Ansic, D. (1997). Gender differences in risk behavior in financial decision-making: An $\begin{array}{llll}\text { experimental analysis. Journal of Economic Psychology, 18, 605-628. } & \text {. }\end{array}$ https://doi.org/10.1016/S0167-4870(97)00026-3

Qing, S., \& Zheng, J. (2013). Unequal pay or unequal job: Effect of hierarchical segregation on gender earning differentials. China Econ., 12(2), 735-756.

Robb, A., \& Wolken, J. (2002). Firm, owner and financing characteristics: Differences between female- and male-owned small businesses. Finance and Economics Discussion Series, Division of Research and Statistics and Monetary Affairs, Federal Reserve Board, Washington, DC No. 2002-18. https://doi.org/10.2139/ssrn.306800

Roomi, M. A., Harrison, P., \& Beaumont-Kerridge, J. (2009). Women-owned small and medium enterprises in England. Journal of Small Business and Enterprise Development, 16(2), 270-288. https://doi.org/10.1108/14626000910956056

Schindehutte, M., Morris, M. H., \& Kocak, A. (2008). Understanding market-driving behavior: The role of entrepreneurship. Journal of Small Business Management, 46(1), 4-26. https://doi.org/10.1111/j.1540-627X.2007.00228.x

St-Cyr, L. (2002). Les femmes entrepreneurs Québécoises: Taille et gestion. Compte rendu d'une recherche, Montréal, École des Hautes Études Commerciales Affiliée a` l'Université de Montréal.

St-Cyr, L., Hountondji, S., \& Beaudoin, N. (2003). Mémoire présenté au Groupe de travail du Premier Ministre sur les femmes entrepreneures, Chaire de développement et de relevé de la PME, École des Hautes Études Commerciales Affiliée a l'Université de Montréal.

Stinerock, R., Stem, B., \& Solomen, M. (1991). Sex and Money: Gender differences in the sue of surrogate consumers for financial decision making. Journal of Professional Services Marketing, 7(2), 167-182. https://doi.org/10.1300/J090v07n02_15 
Trad, M. (2015). Women and entrepreneurship: Evidence from Lebanon and United Arab Emirates. International Journal of Contemporary Management, 14(4), 7-22.

Villasana, M., Alcaraz-Rodríguez, R., \& Alvarez, M. (2016). Examining entrepreneurial attributes of Latin American female university students. Gender and Education, 28(1), 148-166. https://doi.org/10.1080/09540253.2015.1093100

Vogel, P. (2017). From venture idea to venture opportunity. Entrepreneurship Theory and Practice, 41(6), 943-971. https://doi.org/10.1111/etap.12234

Walczak, D., \& Pienkowska-Kamieniecka, S. (2018). Gender Differences in Financial Behaviours. Inzinerine Ekonomika-Engineering Economics, 29(1), 123-132. https://doi.org/10.5755/j01.ee.29.1.16400

Weber, C. S. (2013). Cultural differences in risk tolerance. IWE Working Paper No. 01. Erlangen, Germany.

Welsh, D. H. B., Kaciak, E., \& Thongpapanl, N. (2016). Influence of stages of economic development on women entrepreneurs' startups. Journal of Business Research, 69(11), 4933-4940. https://doi.org/10.1016/j.jbusres.2016.04.055

\section{Notes}

Note 1. Belluchi et al. (2010) show that women entrepreneurs support strict conditions in the loan contract than male: higher collateral, lower credit limits and quicker maturity of the loan on the Italian market using data from 7800 small businesses. Kwong et al. (2012) reveal that women entrepreneurs face more credit constraints than men and they also face discrimination on loan rate, using the GEM (Global Entrepreneurship Monitor) data from 2005- 2007. Qing and Zheng (2013) consider that gender bias hypothesis simply implies that banks may charge higher loan interests and require stricter non-price terms when lending to female entrepreneurs in China.

Note 2. Western Europe countries are defined as a group of countries with broadly similar cultures, including some countries which are excluded from the geographic map of the Western Europe, such as Germany and Vatican City. France, the United Kingdom, Belgium, the Netherlands and Ireland are always considered part of the Western Europe. Often Spain, Portugal, Italy, Vatican City, Monaco and Switzerland are also considered among Western Europe countries. Germany, Liechtenstein, Luxembourg and Austria are sometimes called "Central Europe" countries, but they can be considered part of the Western Europe. To resolve this confusion, Western Europe countries are maximally composed of Portugal, France, Spain, Belgium, Germany, Greece, Switzerland, the Uk, the Netherlands, Ireland, Italy, Vatican City, Monaco, Austria, Luxembourg and Liechtenstein. Retrieved from https://www1.essex.ac.uk/armedcon/world/europe/western_europe/default.html.

Note 3. According to the European commission statistics about women in entrepreneurship, the number of young entrepreneurs is very low in Europe. Only 3\% of women and $2 \%$ of men entrepreneurs are between 15 and 24 years. But, $79 \%$ of women and $78 \%$ of men entrepreneurs aged between 25 and 49 years. European Commission - Statistical Data on Women Entrepreneurs in Europe (2014). Retrieved from http://www.ec.europa.eu.

Note 4. Global Entrepreneurship Monitor, 2016 National Report: Lebanon, Retrieved from http://www.databank.com.lb/docs/ Entrepreneurship \%20in\%202016-GEM-UKLTH.pdf.

Note 5. Retrieved from http://www.globalfemaleleaders.com/blog/women-entrepreneurship-middle-east.

Note 6. The European commission statistics had found that the level of education of women entrepreneurs is very close to the maximum level (2.49 points from 3 points) in 2014. Retrieved from http://www.ec.europa.eu

Note 7. IFC: International Finance Corporation and CAWTAR: Center of Arab Women for Training And Research, Retrieved from http://www.ifc.org/wps /MENA_Women_Entrepreneurs_ExecSum_English.pdf.

Note 8. For example, women entrepreneurs in Lebanon have owned their business for 10.6 years, in Bahrain for 10.2 years, in Jordan for 6.1 years and in the UAE for 5.9 years.

\section{Copyrights}

Copyright for this article is retained by the author(s), with first publication rights granted to the journal.

This is an open-access article distributed under the terms and conditions of the Creative Commons Attribution license (http://creativecommons.org/licenses/by/4.0/). 